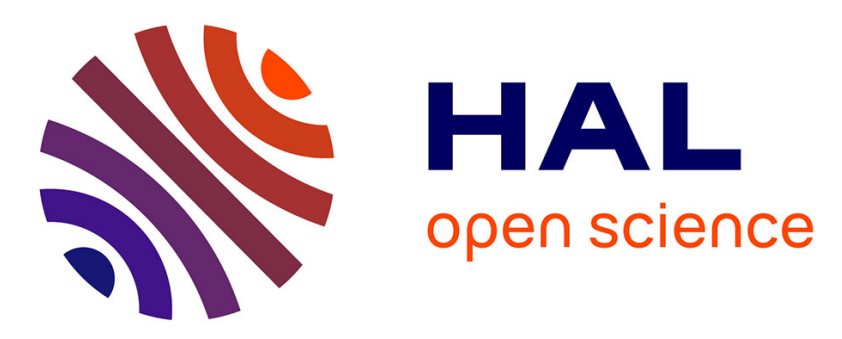

\title{
Patterns of denitrification rates in European alluvial soils under various hydrological regimes
}

G Pinay, B Gumiero, E Tabacchi, O Gimenez, A M Tabacchi-Planty, M M Hefting, T P Burt, V A Black, C Nilsson, V Iordache, et al.

\section{- To cite this version:}

G Pinay, B Gumiero, E Tabacchi, O Gimenez, A M Tabacchi-Planty, et al.. Patterns of denitrification rates in European alluvial soils under various hydrological regimes. Freshwater Biology, 2007, 52 (2), pp.252 - 266. 10.1111/j.1365-2427.2006.01680.x . hal-03498955

\section{HAL Id: hal-03498955 https://hal.science/hal-03498955}

Submitted on 4 Jan 2022

HAL is a multi-disciplinary open access archive for the deposit and dissemination of scientific research documents, whether they are published or not. The documents may come from teaching and research institutions in France or abroad, or from public or private research centers.
L'archive ouverte pluridisciplinaire HAL, est destinée au dépôt et à la diffusion de documents scientifiques de niveau recherche, publiés ou non, émanant des établissements d'enseignement et de recherche français ou étrangers, des laboratoires publics ou privés. 


\title{
Patterns of denitrification rates in European alluvial soils under various hydrological regimes
}

\author{
G. Pinay $^{(1)(2)^{*}}$; B. Gumiero ${ }^{(3)}$; E. Tabacchi ${ }^{(4)}$; O. Gimenez ${ }^{(1)}$; A.M. Tabacchi-Planty ${ }^{(4)}$;

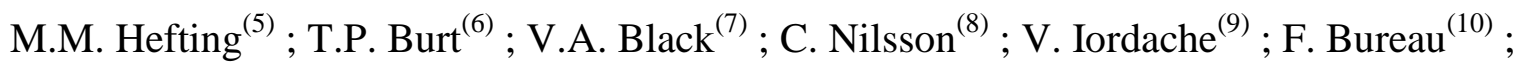 \\ L. Vought ${ }^{(11)}$; G.E. Petts ${ }^{(12)} ;$ H. Décamps ${ }^{(4)}$ \\ (1): Centre d'Ecologie Fonctionnelle \& Evolutive - UMR 5175 - 1919 route de Mende - F-34293 Montpellier cedex 05 France \\ (2): University of Vienna, Department of Limnology \& Hydrobotany - Althanstrasse 14 - A1090 Vienna Austria \\ (3): Department of Ecology, University of Bologna, Via Selmi 3 - 40126 Bologna, Italy \\ (4): LADYBIO, 29 rue Jeanne Marvig, 31055 Toulouse, France \\ (5): Department of Geobiology, University of Utrecht, PO box 80084, TB Utrecht, The Netherlands \\ (6): University of Durham, Department of Geography, Durham DH1 3LE, United Kingdom \\ (7): Loughborough Univ Technol, Dept Geog, Loughborough, Leics LE11 3TU United Kingdom \\ (8): Landscape Ecology Group, Dept Ecology and Environmental Science, Umeå Univ, SE-901 87 Umeå, Sweden \\ (9): Univ Bucharest, Dept Syst Ecol, Spl Independentei 91-95, Bucharest, 76201 Romania \\ (10): University of Rouen, Laboratoire d'écologie ECODIV - UPRES EA 1293 - 76821 Mont Saint Aignan, France. \\ (11): Department of Technics, Kristianstad University, SE-291 88 Kristianstad, Sweden \\ (12): Department of Geography, University of Birmingham, United Kingdom
}

\section{SUMMARY}

1. Denitrification in floodplain soils is one of the main biological processes emitting and reducing nitrous oxide, a greenhouse gas, and the main process responsible for the buffering capacity of riparian zones against diffuse nitrate pollution.

2. The aim of this study was to measure denitrification rates under a wide range of current climatic conditions and hydrological regimes within Europe (from latitude $64^{\circ} \mathrm{N}$ to latitude $42^{\circ} \mathrm{N}$ - and from longitude $2^{\circ} \mathrm{W}$ to longitude $25^{\circ} \mathrm{E}$ ), i) to determine the response patterns of this microbial process under different climatic and hydrological conditions, ii) to identify denitrification proxies robust enough to be used at the European scale.

3. Denitrification activity was significant in all the floodplain soils studied whatever the latitude. However, we found an increase in rates of an order of magnitude from high to mid latitudes. Maximum rates (above $30 \mathrm{~g} \mathrm{~N} \mathrm{~m}^{-2}$ month ${ }^{-1}$ ) were measured in the maritime conditions of the Trent floodplain. These rates are similar to mineralization rates measured in alluvial soils and of the same order of magnitude as the amount of $\mathrm{N}$ stored in herbaceous plants in alluvial soils. 
4. We used Multivariate Adaptative Regression Splines (MARS) to relate the response variable denitrification with five relevant predictors, namely soil moisture, temperature, silt \& clay and nitrate content, as well as herbaceous plant biomass.

5. Soil moisture, temperature, and nitrate were the three main control variables of microbial denitrification in alluvial soils in decreasing order of importance.

6. The model developed for denitrification with interaction effects outperforms a pure additive model. Soil moisture was involved in all interactions, which points out its importance in predicting denitrification.

7. These results are discussed in the context of hydrological regimes change scenario in Europe.

Keywords: riparian zone, river floodplain, microbial process, Europe, Climate change

\section{Introduction}

World wide predicted temperature increases for the $21^{\text {st }}$ century range between $1.4^{\circ} \mathrm{C}$ and $4.7^{\circ} \mathrm{C}$ (Richards, 1993; IPCC, 2001). Although the importance of temperature in regulating physiological processes is unquestionable, predicting the relationship between ecological process and temperature is complicated. Indeed, as the Earth warms, a general intensification of the hydrological cycle is also expected to occur (Miller \& Russell, 1992). Precipitation, evapotranspiration and runoff are all expected to increase together with extremes events, i.e. floods and droughts (Loaiciga et al., 1996). For instance, drastic changes are expected in Bangladesh with a shift in the timing of flood distribution and an increase in their magnitude and duration (Mirza, 2002; Mirza et al., 2003). Consequently, a lot of effort is being placed into modelling change in hydrological regimes (Bailey, 1976; Najjar et al., 2000; Chang et al., 2001; Pabich et al., 2001; Roy et al., 2001; Stone et al., 2001; Burlando \& Rosso, 2002; Benito et al., 2003). However, global-scale generalizations of relationships between climate change and extreme floods is difficult because climate (Nakagawa et al., 2003) and hydrological responses vary regionally (Knox, 1993). For instance, Knox (1993) reported in a 7,000-year geological study on the Upper Mississippi River that small changes in the mean annual temperature $\left(1-2^{\circ} \mathrm{C}\right)$ and mean annual precipitation (10-20\%) can change dramatically the magnitude of floods. 
Several papers have already addressed the water resources implications of global warming, among others Falkenmark et al., 1998; Lettenmaier et al., 1999; Jackson et al., 2001; Middelkoop et $a l ., 2001$. Yet very few authors have considered the ecological impact of climate change on river ecosystems (Poff, 2002). However the functioning of rivers and their floodplains depends to a large extend on periodic flooding; the intensity, timing, frequency and duration of these events are essential to maintaining a mosaic of habitats (Benke et al., 2000) and a high productivity both in rivers and their floodplains (Junk et al., 1989; Naiman \& Décamps, 1997). The high productivity of river ecosystems is largely due to riparian zones which control the energy, nutrients and organic matter fluxes both in longitudinal (Schlosser \& Karr, 1981, Pinay et al., 2000) and lateral directions (Peterjohn \& Correll, 1984, Haycock, Pinay \& Walker, 1997). However, riparian zone's existence is also largely controlled by the timing and duration of flood events (Salo et al., 1986; Gregory et al., 1991; Conner \& Day, 1992; Clawson et al., 2001). More specifically, water regime changes, through alteration of the frequency, duration, and period of occurrence of water levels, directly affect nutrient cycling in alluvial soils by controlling the duration of oxic and anoxic phases (Patrick \& Tusnem, 1972; Ponnamperuma, 1972; Keeney, 1973) and, in turn, affect nitrogen endproducts and availability (Hefting et al., 2004).

In Europe, scenarios of change of the hydrological regime forecast an overall increase in the inter-annual variability of runoff, an increase of the average annual runoff in northern Europe and a decrease in the south (Arnell, 1999). Moreover, the timing and duration of high and low flow events may shift, especially in the eastern part of the continent. Ultimately, these changes will affect the rates of nitrogen cycling in riparian wetlands and their plant productivity. In this context, we focused on denitrification in floodplain soils, one of the microbial processes involved in the nitrogen cycling. This process is interesting for several reasons: It is very sensitive to the redox status of the soils and sediments, which is controlled by the hydrological regime of the rivers (Knowles, 1982). High rates have been measured in floodplain soils (Johnston, 1991; Groffman et al., 1992; Pinay et al., 2000). It is one of the main biological process emitting and reducing nitrous oxide, a greenhouse gas (Groffman et al., 1998; Blitcher-Mathiesen \& Hoffmann, 1999; Hefting et al., 2003). It has been proved to be the main process responsible for the buffering capacities of riparian zones against nitrate diffuse pollution (Peterjohn \& Correll, 1984; Pinay et al., 1993; Haycock et al. 1997; Sabater et al., 2003).

The aim of this study was: i) to measure denitrification rates in floodplain soils under a wide range of current climatic conditions and hydrological regimes within Europe, ii) to 
determine the response patterns of this microbial process under these different climatic conditions, iii) to identify denitrification proxies robust enough to be used at the European scale, and iv) to discuss the possible change of denitrification activity in floodplain soils under forecast climate change scenarios.

\section{Study sites}

We selected seven rivers in Europe to encompass a large range of climatic and hydrological regimes from maritime to continental regions (Fig. 1; Table 1): The Vindel River in the North of Sweden $\left(64^{\circ} \mathrm{N}\right)$ and the Helge River in the South of Sweden $\left(56^{\circ} \mathrm{N}\right)$, the River Trent in the United Kingdom $\left(52^{\circ} \mathrm{N}\right.$ near Nottingham), the Aar River in Switzerland $\left(47^{\circ} \mathrm{N}\right.$ near Meienried), the Garonne River in Southern France (near Toulouse $44^{\circ} \mathrm{N}$ ), the Po River in Northern Italy (near Pontelagoscuro $43^{\circ} \mathrm{N}$ ) and the Danube in Romania (Near Braïla $42^{\circ} \mathrm{N}$ ). In maritime areas, e.g. Trent, the seasonal regime reflects the seasonal variability in rainfall and evapotranspiration. In continental areas, e.g. the Danube, the peak runoff season corresponds to snowmelt. In between these two extremes, there exist many mixed regimes representing local climatic conditions (Krasovskaia et al., 1994; Arnell, 1999). For instance, northern (Vindel River, Helge River) and Alpine regions of Europe (Aar River) have a snowdominated hydrology, while the Garonne and the Po Rivers are influenced both by snowmelt, respectively from the Pyrenees and the Alps mountains, and by the balance of a rainfall and evapotranspiration.

The riparian zones studied were located in the annually flooded alluvial reaches of each river. The main source of nutrient input to the riparian floodplain originated from flood deposits. In most cases, the study sites were forested and included similar species or genera at each site. The most common genera were willow (Salix), alder (Alnus), oak (Quercus), elm (Ulmus), and poplar (Populus). The main species of the understorey varied between regions: Carex and Calamagrostis in the Vindel River, Phragmites and Deschampsia in the Helge River, Urtica and Phragmites in the Aar River, stinging nettle (Urtica) and Impatiens in the Trent and the Garonne Rivers, Solidago and Urtica in the Po River, Agrostis and Bidens in the Danube River. At the Swedish sites, the soils were typical podzols, which were regularly flooded. At the other sites, the soils belonged to the Fluvents series of alluvial entisoils.

\section{Materials \& Methods}

River discharge and rainfall were monitored by hydrometric stations near the study sites in each country. Within each river valley, five to ten forested riparian locations were selected in 
different geomorphological contexts, i.e. meandering and straight channels, different soil grain size, but at the same relative altitude to ensure similar flooding duration and frequency. This sampling effort represents altogether about 2500 different samples collected between 1996 and 1999. At each location, three different plots, each of one square meter, were chosen monthly. At each site above-ground herbaceous vegetation was harvested monthly (except when soil was frozen) and oven-dried at $60^{\circ} \mathrm{C}$ to determine the dry mass. Soil temperature was measured hourly using a datalogger (Tinytalk II; Gemini Dataloggers, U.K., range $-10+40^{\circ} \mathrm{C}$ ).

At each quadrat, a composite soil sample was collected from the upper $10 \mathrm{~cm}$ of soil, the most active zone in a biological sense, after the litter was discarded. A sub-sample was oven-dried for $24 \mathrm{~h}$ at $105^{\circ} \mathrm{C}$ to determine fresh and dry mass and percent moisture. Percentage of sand was determined by sieving (50 $\mu \mathrm{m}$ mesh) after pre-treating the samples with hydrogen peroxide and dispersal with sodium hexametaphosphate solution (Day, 1965). Ten grams (fresh mass) of each soil sample were extracted with $150 \mathrm{ml}$ of $2 \mathrm{M} \mathrm{KCl}$. The extract was filtered and analysed for $\mathrm{N}-$ $\mathrm{NO}_{3}-\mathrm{N}$ with a Technicon Autoanalyzer (Technicon, 1976). Nitrate is expressed in $\mathrm{g} \mathrm{N}-\mathrm{NO}_{3} \mathrm{~m}^{-2}$ of soil.

Denitrification (DNT) was assayed by the static core acetylene inhibition method (Yoshinari \& Knowles, 1976). Nine intact cores (length $10 \mathrm{~cm}$, diameter $5 \mathrm{~cm}$ ) collected monthly or every two months from each of the 15 sites were capped with rubber serum stoppers and then amended with acetone-free acetylene to bring core atmosphere concentration to $10 \mathrm{KPa}(10 \% \mathrm{~V} / \mathrm{v})$ acetylene and $90 \mathrm{kpa}$ air. These cores were incubated at field temperature for periods of between 1 and $4 \mathrm{~h}$, and the rate of denitrification calculated as the rate of nitrous oxide $\left(\mathrm{N}_{2} \mathrm{O}\right)$ accumulation in the head space in 4 hours. Head-space gas samples were removed from all cores, stored in evacuated collection tubes (Venoject, Terumo Scientific N.J), sent to Toulouse, and subsequently analysed within a few days using a gas chromatograph (GC Varian 3300) equipped with an electron capture detector $\left(E C D{ }^{63} \mathrm{Ni}\right)$ and Porapak Q columns. Results are expressed in $\mathrm{g} \mathrm{N} \mathrm{m}^{-2}$ month $^{-1}$ with the assumption that the value measured is somehow representative of the 2 weeks before and 2 weeks after the sampling time. Even though it is well known that the acetylene block method has some problems; it is a reasonably robust method, especially with systems with moderate or high nitrate fluxes such as riparian soils. See Groffman et al., (2006) for a review. Therefore it provides a fair estimate of denitrification rates when applied on short term essays and allows inter sites comparisons.

\section{Statistical analyses}


We used Multivariate Adaptative Regression Splines (MARS) to relate the response variable denitrification with five relevant predictors, namely soil silt plus clay (\%), herbaceous plant biomass ( $\mathrm{g}$ dry mass $/ \mathrm{m}^{2}$ ), soil moisture $(\%), \mathrm{g} \mathrm{N}-\mathrm{NO} 3\left(\mathrm{~m}^{-2}\right)$ and temperature $\left({ }^{\circ} \mathrm{C}\right)$. Introduced by Friedman (1991), MARS approximates the underlying relationship between the response variable and the predictors using a set of adaptative piecewise linear regressions called basis functions $(\mathrm{BFs})$. A typical BF is $\max (0, \mathrm{x}-\mathrm{c})$ (resp. $\max (0, c-x))$ taking values $\mathrm{x}($ resp. $-\mathrm{x})$ for all values of $\mathrm{x}$ greater (resp. lower) than some threshold $\mathrm{c}$ and 0 otherwise. The constant $\mathrm{c}$ is usually referred to as knot where a change in the slope of the BF occurs. MARS models were fitted using the MARS software (Salford Systems, http://www.salford-systems.com/mars.php). Because results produced by MARS can be affected by multicolinearity in the set of explanatory variables, we checked that the predictors were uncorrelated using standard Pearson correlations and a principal component analysis (results not shown).

\section{Results}

\section{European scale}

We combined all the data from the different study sites, sampling locations and sampling dates to analyse the patterns of denitrification rates at the European scale. Several local studies have already shown that soil temperature, moisture and grain size influence denitrification rates. The objective here was to determine whether these simple parameters could be used as proxy of denitrification activity at the large scale; in other words, if they would be robust enough to encompass local, regional and seasonal variability. Our expectation was that denitrification activity would be positively correlated to alluvial soil moisture and temperature. We found a high variability in denitrification rates ranging from zero to $30 \mathrm{~g} \mathrm{~N} \mathrm{~m}^{-2}$ month $^{-1}$ (Fig. 2). Maximum denitrification activity was not found at maximum soil moisture but between 50 and $80 \%$ weight/weight (Fig. 2A). The relationship between denitrification activity and soil grain size was not linear either (Fig. 2B). The highest denitrification activity was measured in soil with ca $80 \%$ silt \& clay. A negative exponential relationship was found between soil nitrate content and denitrification activity (Fig. 2C). High denitrification rates were measured in soils with low to medium nitrate concentration. Moreover, at this large scale of analysis there was also a negative exponential relationship between denitrification rates in alluvial soils and herbaceous biomass production (Fig. 2D). Highest denitrification activity was measured in soils with low herbaceous biomass 
production. At this European scale denitrification presented a bimodal pattern with high rates at both low (ca 5-10 ${ }^{\circ} \mathrm{C}$ ) and mild (ca $\left.15-20^{\circ} \mathrm{C}\right)$ soil temperature (Fig. 2E).

We used Multivariate Adaptative Regression Splines (MARS) to relate the response variable denitrification with five relevant predictors, namely soil silt \& clay (SC \%), herbaceous plant biomass (HPB g dry mass $\left./ \mathrm{m}^{2}\right)$, soil moisture $(\mathrm{SM} \%)$, nitrate $(\mathrm{N}$ g N-NO $\mathrm{m}^{-2}$ ) and temperature $\left(\right.$ TEMP $\left.{ }^{\circ} \mathrm{C}\right)$. The MARS algorithm searches for the optimal combination of BFs therefore allowing maximum flexibility in describing any functional - including nonlinear - form of the response variable.

The basis functions selected by MARS were:

$$
\begin{aligned}
& \mathrm{BF} 1=\max (0, \mathrm{SM}-77.390) ; \\
& \mathrm{BF} 2=\max (0,77.390-\mathrm{SM}) ; \\
& \mathrm{BF} 3=\max (0, \mathrm{~N}-1.660) ; \\
& \mathrm{BF} 4=\max (0,1.660-\mathrm{N}) ; \\
& \mathrm{BF} 6=\max (0,17.000-\mathrm{TEMP}) ; \\
& \mathrm{BF} 7=\max (0, \mathrm{SM}-56.310) \times \mathrm{BF} 6 ; \\
& \mathrm{BF} 9=\max (0, \mathrm{SM}-75.120) \times \mathrm{BF} 3 ; \\
& \mathrm{BF} 11=\max (0, \mathrm{SM}-58.310) ; \\
& \mathrm{BF} 13=\max (0, \mathrm{TEMP}-15.780) \times \mathrm{BF} 11 ; \\
& \mathrm{BF} 14=\max (0,15.780-\mathrm{TEMP}) \times \mathrm{BF} 11 ; \\
& \mathrm{BF} 15=\max (0, \mathrm{HPB}+.120690 \mathrm{E}-04) ;
\end{aligned}
$$

and the final model for denitrification is:

Denitrification $=55.127+3.531 \times \mathrm{BF} 1-0.728 \times \mathrm{BF} 2+31.947 \times \mathrm{BF}-1.471 \times \mathrm{BF} 6$ $-0.950 \times \mathrm{BF} 7-1.789 \times \mathrm{BF} 9+3.554 \times \mathrm{BF} 13+1.159 \times \mathrm{BF} 14-0.010 \times \mathrm{BF} 15$;

From this equation, it is clear that a model with interaction effects outperforms a pure additive model, which is confirmed by the difference in Generalized Cross-Validation (GCV) of the two models, 493.562 vs. 529.599 respectively. Interestingly, the explanatory variable Soil Moisture is involved in all interactions through basis functions BF7, BF9 and BF11, which points out its importance in predicting denitrification. In Table 2 we presented the ranking of predictors for denitrification by order of importance (\%), which is the relative importance of predictors as compared to the best one (soil moisture here). It confirms that soil moisture was the most important variable determining denitrification, and to a lesser extent by order of 
importance temperature, nitrate, then marginally herbaceous plant biomass. It is interesting to note that soil texture (silt \& clay content, i.e. SC) did not play any role in the final model.

\section{River scale}

The relationship between denitrification activity and alluvial soil temperature was reanalysed at the local scale, considering the denitrification patterns river by river (Fig 3). The lowest denitrification rates were measured in the Vindel and the Helge alluvial soils but they were of the same order of magnitude as the values obtained at the other sites. Different seasonal patterns were found across Europe: in the Vindel, Helge, Aar and Danube Rivers, which correspond respectively to cold high latitude, high altitude and continental sites, denitrification rates were higher at highest temperatures characteristic of the period from mid spring to late summer. In these sites, no significant denitrification rates were measured at times of low temperature. In the Trent, Garonne and Po rivers, corresponding respectively to oceanic and warm temperate climates, denitrification rates showed a bimodal pattern being higher at both high and low (i.e. $3-5^{\circ} \mathrm{C}$ ) soil temperatures.

Detailed analysis of the temporal pattern of denitrification in the Garonne alluvial soils, for instance, revealed that both rainfall and flood events can trigger microbial activity (Fig. 4). High denitrification rates were measured with high soil temperature and moderate rainfall (Fig. 4A). However, during high-water periods and various rainfall events, high denitrification rates were also measured even at times of low soil temperature (Fig. 4B). Similarly, rainfall and flood events can cause high denitrification rates in the alluvial soils of the Po River (Fig 5) under a wide range of soil temperatures (from 5 to $20^{\circ} \mathrm{C}$ ). Even a relatively brief rainfall event (100 $\mathrm{mm}$ in two days in June Fig. 5D2) in an otherwise dry period can trigger high denitrification rates.

\section{Discussion}

\section{Patterns of denitrification activity and controlling factors at the European scale}

Denitrification activity was significant in all the floodplain soils regardless the latitude (Fig. 2E). Yet, we found a difference in rates of an order of magnitude from the high to the mid latitudes. Maximum rates (above $30 \mathrm{~g} \mathrm{~N} \mathrm{~m}^{-2} \mathrm{month}^{-1}$ ) were measured in the maritime conditions of the Trent floodplain (Fig. 3). These rates are in accordance with those measured in other wetland sites (Merrill \& Zak, 1992; Pinay et al., 1993; Naiman et al., 1994; Johnston et al., 2001; Pinay et al., 2003). 


\section{Soil moisture}

The most important control variable was soil moisture, which was controlled by hydrological events. This was confirmed by the MARS analysis. Soil moisture was involved in all interactions through basis functions BF7, BF9 and BF11, which points out its importance in predicting denitrification. Flooding frequency and duration are controlled by local topography; low areas being flooded more frequently and for longer periods than higher ones, producing large variations in biogeochemical patterns at the metre scale (Pinay et al., 1989; Pinay \& Naiman, 1991). Biogeochemical processes, especially for nitrogen, are sensitive to the oxidation status of the soil. For instance, ammonification of organic nitrogen can be realized both under aerobic and anaerobic conditions. Nitrification process, which is strictly aerobic, can occur only in aerated soils or sediments. As a consequence, in permanently anaerobic conditions, the organic nitrogen mineralization processes result in the accumulation of ammonia.

Other processes such as nitrogen dissimilation or denitrification are strictly anaerobic, requiring saturated soils to operate. Therefore the end products of nitrogen cycling in riparian soils are directly controlled by the groundwater table with important implications for floodplain productivity. Even so, maximum denitrification activity was not found at soil saturation but between 60 and $80 \%$ of maximum soil moisture (Fig. 2A). This can be explained by the fact that partial waterlogging conditions favour the co-existence of aerobic and anaerobic sites at the soil micro-scale. This, in turn, allows the occurrence in nearby microsites of both strictly aerobic and anaerobic biogeochemical processes involved in the nitrogen cycle and enhances organic matter decomposition and nitrogen loss through denitrification in flooded soils (Reddy \& Patrick, 1975; Groffman \& Tiedje, 1988). Similarly, alternate aerobic and anaerobic conditions triggered by short-term periodicity of flooddrainage cycles or short rainfall events (Fig. 5) will provide similar results and therefore enhance denitrification process, providing that soil temperature is above $0^{\circ} \mathrm{C}$.

\section{Soil Temperature}

The second most important control variable which was confirmed by the MARS analysis was soil temperature (Table 2). At the European scale denitrification presented a bimodal pattern with high rates at both low and mild soil temperature (Fig. 2E). It was found that in cold winter regions, i.e. high latitudes (Vindel and Helge Rivers), high altitudes (Aar River) and continental regions (Danube River), very low temperatures during the winter period limits microbial activity in general and denitrification in particular (Fig. 3). Therefore, 
whatever the hydrologic event, flood or rainfall, it did not trigger any significant denitrification activity during these low-temperature periods. Under milder winter conditions, i.e. Trent, Garonne and Po Rivers, denitrification rates could be significant throughout the year (Fig. 3). Flooding or rainfall could cause high denitrification rates (Figs. $4 \& 5$ ) by controlling waterlogging conditions in the alluvial soils and the duration of oxic and anoxic phases (Ponnamperuma, 1972; Keeney, 1973; Patrick, 1982).

\section{Nitrate}

The third control variable on denitrification after soil temperature and soil moisture, confirmed by the MARS analysis, was soil nitrate concentration (Table 2). At the microbial scale, nitrate is a limiting factor for denitrification. Yet, the global negative relationship between denitrification activity and soil nitrate content (Fig. 2C) reveals that nitrate can be used as proxy to determine whether denitrification occurs in alluvial soils. Yet, low or medium soil nitrate concentrations do not provide much information on the rate of nitrogen turn over in alluvial soils because we measured a wide range of denitrification rates under these soil nitrate concentration. High denitrification rates measured in soils with low nitrate concentration suggest that denitrification rates are of the same order of magnitude as $\mathrm{N}$ mineralization rates. See Johnston, (1991) for a review.

\section{Herbaceous plant biomass}

Competition between plant and denitrification for $\mathrm{N}$ uptake in floodplain soils entails negative exponential relationship between herbaceous plant biomass and denitrification (Fig. 2D). It was a significant variable in the denitrification model developed by the MARS procedure (Table 2). Considering that herbaceous plant biomass contains an average of $2 \%$ $\mathrm{N}$; then the $\mathrm{N}$ denitrified in alluvial soil is in the same order of magnitude as the $\mathrm{N}$ stored in herbaceous plants (Fig. 2D). Yet, denitrification constitutes a true removal of $\mathrm{N}$ since the end products are in gaseous form (Knowles, 1982). Consequently denitrification represents a significant loss of nitrogen from floodplain systems; its increase could limit plant biomass production.

\section{Soil texture}

Denitrification activity was low in alluvial soils with a low percentage of silt and clay (Fig. 2B). Above a threshold of ca. $60 \%$ of silt and clay we measured the highest rates of denitrification activity. This threshold was found whatever the site considered. Interestingly, at this European 
scale, silt \& clay content was not considered in our model to be a significant variable to estimate denitrification in alluvial soils. Yet, the role of soil texture in controlling nitrogen cycling has been already documented in forests (Pastor et al., 1984; McClaugherty et al., 1985), coastal forests (Seely et al., 1998), short-grass steppe (Schimel et al., 1985), desert ecosystems (Schlesinger et $a l ., 1996)$ and grassland (Parton et al., 1988). We know also that flooding indirectly affects nutrient cycling and especially denitrification in floodplain soils by influencing the soil structure and texture through sediment deposits (Pinay et al., 1995; Pinay et al., 2000). Hence, locally, floodplain and stream channel hydromorphological processes influence the sorting of flood sediment deposits on a grain size basis creating a mosaic of soils of different textures. However, sediment texture does not seem to be an important variable at the European scale.

\section{Possible changes in denitrification activity patterns under climatic change scenario}

Bacterial denitrification activity is a key process in the cycling of $\mathrm{N}$ in floodplain soils since it constitutes a major sink for nitrate, and as such is involved in the control of nitrogen fluxes along river systems. The denitrification rates measured in this pan-European study confirm also that this process is important in a wide range of climatic conditions. Yet, the construction of predictive models of $\mathrm{N}$ cycling in floodplain soils is extremely difficult because of the often episodic nature of flood and rainfall events. Moreover, the development of predictive models necessitates that a link be established between processes occurring at a microbial scale and landscape patterns visible at the floodplain scale. For instance, although the role of soil moisture, nitrate concentration and available carbon in regulating this microbial process is now well documented (Rolston et al., 1984; Myrold \& Tiedje, 1985; Davidson \& Swank, 1986), these three factors do not explain fully the variation in the denitrification rates observed at the floodplain scale. Indeed, we found that the main driving factors of microbial denitrification in alluvial soils are soil moisture, temperature and to a lesser extend soil nitrate concentration. These three factors might well be affected by global change (Shaver et al., 2000; Georgakakos \& Smith, 2001). Indeed geomorphological and hydrological processes can be altered both from the upslope by land use/land cover change and from the river discharge changes (Nilsson \& Berggren, 2000; Nijssen et al., 2001; Burt et $a l ., 2002$; Pinay et $a l ., 2002)$ while temperature should rise under atmospheric carbon dioxide concentration increase (IPCC, 2001). Yet there remains a major difficulty under climate change scenarios to estimate the resulting hydrological changes since the modelling of their components, i.e. precipitation, evapotranspiration, soil moisture and runoff in considerably less reliable than modelling temperature and pressure for instance (Jones \& Woo, 2002). 
Moreover, the effect of a change in climate on the natural hydrological system is frequently non-linear due to the existence of critical thresholds (Arnell, 2000). For instance, even as the Earth as a whole continues to warm gradually, large regions may experience a rapid shift into colder climate (Peterson et al., 2002).

Despite these uncertainties, there is evidence from Quaternary records that impact of climate change on fluvial dynamics is more significant in the upper reaches of river networks (Veldkamp \& Tebbens, 2001). Therefore, signs of hydrological changes due to climate change are expected to be less marked in the lower part of the Danube River than in the other study sites, for instance. The 4 scenarios of climatic change, i.e. UKHI (Mitchell et al., 1990); UKTR (Murphy \& Mitchell, 1994), CCC (Boer et al., 1992), GHGx, (Johns et al., 1997) used by Arnell, (1999) to evaluate the hydrological change in Europe consistently assume an increase of precipitation and average annual runoff in northern Europe and a decrease of both precipitation and runoff in southern Europe. In cold regions, the timing of flow through the year should be unaffected but we can expect an increase in the spring streamflow peak in response to an increase winter precipitation stored as snow (Nijssen et al., 2001). This should potentially trigger both an increase of denitrification rates and duration in alluvial soils like in the Vindel River in Northern Sweden. A temperature rise will reduce the snow cover at the margin between maritime and continental regimes which will reduce spring flow and increase winter flows in these areas. This shift in the high-water period could reduce denitrification activity since waterlogging conditions would occur under colder temperature conditions in areas such as the Helge River region in the southern part of Sweden. In maritime regions such as in the Trent valley in the United Kingdom, an increase of both the frequency and magnitude of flooding events is expected (Reynard et al., 2001).

If there is still no firm evidence of change in flooding trends due to climate change, by contrast, a number of studies have suggest that rainfall becomes more variable and that rainfall intensity and frequency has increased (Osborn \& Hulme, 2002; Robson, 2002; Burt \& Horton, 2003). This increase of rainfall variability should increase the frequency of aerobicanaerobic cycles in alluvial soils and therefore increase the denitrification activity. This high frequency of wet-dry cycles might increase the proportion of $\mathrm{N}_{2} \mathrm{O}$ emission by denitrification and contribute to the increase the greenhouse effect (Blitcher-Mathiesen \& Hoffmann, 1999; Jacinthe et $a l ., 2000)$. In warmer regions such as those represented by the Garonne River in South West France and the Po River in northern Italy, a decrease in annual rainfall is expected together with an increase of heavy summer rainfall events. Our results show that these alluvial soils, i.e. Garonne and Po River (Figs. 4 \& 5) are highly reactive to such short-term rain 
events, which result in high rates of denitrification activity. One can expect that an increase of these summer rainfall events would increase the loss of nitrogen in alluvial soils during the vegetated period, might increase the competition for $\mathrm{N}$ and, in turn, alter the productivity of these riparian zones.

\section{New challenge}

It is now recognized that the importance of indirect effects of climate change such as hydrological changes on the structure and function of ecosystems may have more effects than the increase of temperature per se (Vitousek, 1994; Pace \& Groffman, 1998). In this study we showed that microbial denitrification, an important process of $\mathrm{N}$ cycling in alluvial soils, had a pattern of activity which varied widely with the regional climatic context. Even so, it was possible to identify the main control variables of denitrification at the European scale, i.e. soil moisture and temperature, and provide a model to forecast denitrification in alluvial soils which could be used to predict the response of alluvial soils to climatic and anthropogenic changes. For instance, two thirds of the freshwater flowing to the oceans is obstructed by large dams (Nilsson \& Berggren, 2000). This is especially true in the Northern Hemisphere and particularly in Europe and North America so that it is possible that hydraulic engineering has produced both local and global-scale impacts on the terrestrial water cycle (Vörösmarty \& Sahagian, 2000). The new challenge today is to decouple the relative impact of direct human intervention from those effects due to climate change and determine the consequences of hydrological variations fostered by climate change on the resistance and resilience of biogeochemical cycles in river systems.

\section{Acknowledgements}

These results arose from the European River Margins programme (ERMAS), which was supported by a European Grant from the Environment and Climate Program (ENV5VCT92-0100). We would like to thank Dr. H. Barth, EU scientific advisor, for his support and our colleagues from the different teams in Europe which helped collecting and analysing the data. We also thank two anonymous reviewers who provided constructive comments on an earlier version of the manuscript.

\section{References}

Arnell N.W., (1999) The effect of climate change on hydrological regimes in Europe: a continental perspective. Global Environmental Change, 9, 5-23. 
Arnell N.W., (2000) Thresholds and response to climate change forcing: the water sector. Climatic Change, 46, 305-316.

Bailey L.D., (1976) Effects of temperature and root on denitrification in soil. J. Soil Science, 56, 79-87.

Benito G., Diez-Herrero A. \& Villalta M.F., (2003) Magnitude and frequency of flooding in the Tagus Basin (Central Spain) over the last Millennium. Climatic Change, 58, 171192.

Benke A.C., Chaubey I., Ward G.M. \& Dunn E.L., (2000) Flood pulse dynamics of an unregulated river floodplain in the Southeastern U.S. coastal plain. Ecology, 8, 27302741.

Blitcher-Mathiesen G. \& Hoffmann C.C (1999) Denitrification as a sink for dissolved nitrous oxide in freshwater riparian fen. Journal of Environmental Quality, 28, 257-262.

Boer G.J., McFarlane N.A. \& Lazare M., (1992) Green-house gas induced climate change simulated with the CCC second generation General Circulation Model. Journal of Climate, 5, 1045-1077.

Burlando P \& Rosso R., (2002) Effects of transient climate change on basin hydrology. 1. Precipitation scenarios for the Arno River, Central Italy. Hydrological Processes, 16, 1151-1175.

Burt T.P. \& Horton B.P., (2003) The climate of Malham Tarn. Field Studies, 10, 635-652.

Burt T.P., Pinay G., Matheson F.E., Haycock N.E., Butturini A., Clément J.C., Danielescu S., Dowrick D.J., Hefting M.M, Hillbricht-Ilkowska A. \& Maitre V., (2002) Water table fluctuations in the riparian zone: comparative results from a pan-European experiment. Journal of Hydrology, 265, 129-148.

Chang H., Evans B.M. \& Easterling D.R., (2001) The effects of climate change on stream flow and nutrient loading. Journal of the American Water Resources Association, 37, 973-985.

Clawson R.G., Lockaby B.G. \& Rummer B., (2001) Changes in production and nutrient cycling across a wetness gradient within a floodplain forest. Ecosystems, 4, 126-138.

Conner W.H. \& Day J.W., (1992) Water level variability and litterfall productivity of forested freshwater wetlands in Louisiana. American Midland Naturalist, 128, 237-245.

Davidson E.A. \& Swank W.T., (1986) Environmental parameters regulating gaseous nitrogen losses from two forested ecosystems via nitrification and denitrification. Applied and Environmental Microbiology, 52, 1287-1292.

Day PR (1965) Particle fractionation and particle-size analysis. In Black CA (Ed) Methods of Soil Analysis. Agronomy 9: 545-567.

Falkenmark, M., W. Klohn, S. Postel, J. Rockstrom, D. S. D, H. Shuval, and J. Wallace. 1998. Water scarcity as a key factor behind global food insecurity: Round table discussion. Ambio 27:148-154.

Friedman, J.H. 1991. Multivariate adaptive regression splines, Annals of Statistics 19: 1-141.

Georgakakos, K. P., and D. E. Smith. 2001. Soil moisture tendencies into the next century for the conterminous United States. Journal of Geophysical Research 106:27,361-327,382.

Gregory, S. V., F. J. Swanson, W. A. McKee, and K. W. Cummins. 1991. An ecosystem perspective of riparian zone. Bioscience 41:540-550.

Groffman P.M., Altabet M.A., Böhlke J.K., Butterbach-Bahl K., David M.B., Firestone M.K., Giblin A.E., Kana T.M., Nielsen L.P. \& Voytek M.A. 2006. Bad solutions to a difficult problem: Methods for measuring denitrification. Ecological Applications, (in press).

Groffman, P. M., A. J. Gold, and P. A. Jacinthe. 1998. Nitrous oxide production in riparian zones and groundwater. Nutrient Cycling in Agroecosystems 52:179-186.

Groffman, P. M., A. J. Gold, and R. C. Simmons. 1992. Nitrate dynamics in riparian forests: microbial studies. Journal of Environmental Quality 21:666-671. 
Groffman, P. M., and J. M. Tiedje. 1988. Denitrification hysteresis during wetting and drying cycles in soil. Soil Science Society of America Journal 52:1626-1629.

Haycock N.E., Pinay G., \& Walker C. (1993) Nitrogen retention in river corridors. European perspective. Ambio, 22 340-346.

Haycock, N. E., T. P. Burt, K. W. T. Goulding, and G. Pinay. 1997. Buffer Zones: Their Processes and Potential in Water Protection. Quest Environmental, Harpenden, UK.

Hefting, M., J. C. Clément, D. Dowrick, A. C. Cosandey, S. Bernal, C. Cimpian, A. tatur, T. P. Burt, and G. Pinay. 2004. Water table elevation controls on soil nitrogen cycling in riparian wetlands along a European climatic gradient. Biogeochemistry 67:113-134.

Hefting, M. M., R. Bobbink, and H. D. Caluwe. 2003. Nitrous oxide emission and denitrification in chronically nitrate-loaded riparian buffer zones. Journal of Environmental Quality 32:1194-1203.

IPCC. 2001. Climate Change 2001: The scientific Basis. Contribution of Working Group I to the third assessment report of the intergouvernemental panel on climate change. Cambridge University Press, Cambridge, U.K.

Jacinthe, P. A., W. A. Dick, and L. C. Brown. 2000. Bioremediation of nitrate-contaminated shallow soils and waters via water table management techniques: evolution and release of nitrous oxide. Soil Biology Biochemistry 32:371-382.

Jackson, R. B., S. R. Carpenter, C. N. Dahm, D. M. McKnight, R. J. Naiman, S. L. Postel, and S. W. Running. 2001. Water in a changing world. Ecological Applications 11:10271045.

Johns, T. C., R. E. Carnell, and J. F. Crossley. 1997. THe second Hadley Centre coupled ocean-atmosphere GCM: model description, spinup and validation. Climate Dynamics 13:103-134.

Johnston, C. A. 1991. Sediment and nutrient retention by freshwater wetlands: effects on surface water quality. Critical Reviews in Environmental Control 21:491-565.

Johnston, C. A., S. D. Bridgham, and J. P. Schubauer-Breigan. 2001. Nutrient dynamics in relation to geomorphology of riverine wetlands. Soil Science Society of America Journal 65:557-577.

Jones, J. A. A., and M. K. Woo. 2002. Modelling the impact of climate change on hydrological regimes. Hydrological Processes 16:1135.

Junk, W. B., P. B. Bayley, and R. E. Sparks. 1989. The flood pulse concept in river-floodplain systems. Fisheries and Aquatic Sciences 106:110-127.

Keeney, D. R. 1973. The nitrogen cycle in sediment-water systems. Journal of Environmental Quality 2:15-29.

Knowles, R. 1982. Denitrification. Microbiological Reviews 46:43-70.

Knox, J. C. 1993. Large increases in flood magnitude in response to modest changes in climate. Science 361:430-432.

Lettenmaier, D. P., A. W. Wood, R. N. Palmer, E. F. Wood, and E. Z. Stakhiv. 1999. Water resources implications of global warming: a US Regional perspective. Climatic Change 43:537-579.

Loaiciga, H. A., J. B. Valdes, R. Vogel, J. Garvey, and H. Schwartz. 1996. Global warming and the hydrological cycle. Journal of Hydrology 174:83-127.

McClaugherty, C. A., J. Pastor, and J. D. Aber. 1985. Forest litter decompositionin relation to soil nitrogen dynamics and litter quality. Ecology 66:266-275.

Merrill, A. G., and D. R. Zak. 1992. Factors controlling denitrification rates in upland and swamp forests. Canadian Journal of Forest Research 22:1597-1604.

Middelkoop, H., K. Daamen, D. Gellens, W. Grabs, J. C. J. Kwadjik, H. Lang, B. W. A. H. Parmet, B. Schädler, J. Schulla, and K. Wilke. 2001. Impact of climate change on 
hydrological regimes and water resources management in the Rhine Basin. Climate Change 49:105-128.

Miller, J. R., and G. L. Russell. 1992. The impact of global warming on river runoff. Journal of Geophysical Research 97:2757-2764.

Mirza, M. M. Q. 2002. Global warming and changes in the probability of occurence of floods in Bangladesh and implications. Global Environmental Change 12:127-138.

Mirza, M. M. Q., R. A. Warrick, and N. J. Ericksen. 2003. The implications of climate chnage on floods of the Ganges, Brahmaputra and Meghna Rivers in Bangladesh. Climatic Change 57:287-318.

Mitchell, J. F. B., S. Manabe, V. Meleshko, and T. Tokiota. 1990. Equilibrium climate change and its implication for the future. Pages 137-164 in J. T. Houghton, G. J. Jenkins, and J. J. Ephraums, editors. Climate change: the IPCC Scientific assessment. Cambridge University Press, Cambridge.

Murphy, J. M., and J. F. B. Mitchell. 1994. Transient response of the Hadley Centre coupled ocean-atmosphere model to increasing carbon dioxide. part II: spatial and temporal structure of response. Journal of Climate 8:57-80.

Myrold, D. D., and J. M. Tiedje. 1985. Establishment of denitrification capacity in soils: Effects of carbon nitrate and moisture. Soil Biology \& Biochemistry 17:819-822.

Naiman, R. J., and H. Décamps. 1997. The ecology of interfaces: riparian zones. Annual Review of Ecology and Systematics 28:621-658.

Naiman, R. J., G. Pinay, C. A. Johnston, and J. Pastor. 1994. Beaver Influences on the LongTerm Biogeochemical Characteristics of Boreal Forest Drainage Networks. Ecology 75:905-921.

Najjar, R. G., H. A. Walker, P. J. Anderson, E. J. BArron, R. J. Bord, J. R. Gibson, V. S. Kennedy, C. G. Knight, J. P. Megonigal, R. E. O'Connor, C. D. Polsky, N. P. Psuty, B. A. Richards, L. G. Sorenson, E. M. Steele, and R. S. Swanson. 2000. The potential impacts of climate change on the mid-atlantic coastal region. Climate Research 14:219233.

Nakagawa, T., H. Kitagewa, Y. Yasuda, P. E. Tarasov, K. Nishida, K. Gotanda, and Y. Sawai. 2003. Asynchronous climate change in the North Atlantic and Japan during the last termination. Science 299:688-691.

Nijssen, B., G. M. O'Donnell, A. F. Hamlet, and D. P. Lettenmaier. 2001. Hydrologic sensitivity of global rivers to climate change. Climate Change 50:143-175.

Nilsson, C., and K. Berggren. 2000. Alterations of riparian ecosystems caused by river regulation. Bioscience 50:783-792.

Osborn, T. J., and M. Hulme. 2002. Evidence for trends in heavy rainfall events over the UK. Philosophical Transactions of the Royal Society of London Series A, 360:1313-1325.

Pabich, W. J., I. Valiela, and H. F. Hemond. 2001. Relationship between DOC concentration and vadose zone thickness and depth below water table in groundwater of Cape Cod, USA. Biogeochemistry 55:247-268.

Pace, M. L., and P. M. Groffman, editors. 1998. Successes, limitations and frontiers in ecosystem science. Springer, New York.

Parton, W. J., A. R. Mosier, and D. S. Schimel. 1988. Rates and pathways of nitrous oxide production in a shortgrass steppe. Biogeochemistry 6:45-58.

Pastor, J., J. D. Aber, C. A. McClaugherty, and J. M. Melillo. 1984. Aboveground production and $\mathrm{N}$ and $\mathrm{P}$ cycling along a nitrogen mineralization gradient on Blackhawk Island, Wisconsin. Ecology 65:256-268.

Patrick, W. H., and M. E. Tusnem. 1972. Nitrogen loss from flooded soils. Ecology 53:735737. 
Patrick, W. J. 1982. Nitrogen transformations in submerged soils. Pages 449-465 in F. J. Stevenson, editor. Nitrogen in Agricultural Soils. Agronomy Monograph.

Paul, E. A., and F. E. Clark. 1996. Soil Microbiology and Biochemistry (second edition). Academic Press.

Peterjohn, W. T., and D. L. Correll. 1984. Nutrient dynamics in an agricultural watershed: Observations on the role of a riparian forest. Ecology 65:1466-1475.

Peterson, B. J., R. M. Holmes, J. W. McClelland, C. J. Vörösmarty, R. B. Lammers, A. I. Shiklomanov, I. A. Shiklomanov, and S. Rahmstorf. 2002. INcreasing river discharge to the Arctic ocean. Science 298:2171-2173.

Pinay, G., V. J. Black, A. M. Planty-Tabacchi, B. Gumiero, and H. Decamps. 2000. Geomorphic control of denitrification in large river floodplain soils. Biogeochemistry 50:163-182.

Pinay, G., J. C. Clement, and R. J. Naiman. 2002. Basic principles and ecological consequences of changing water regimes on nitrogen cycling in fluvial systems. Environmental Management 30:481-491.

Pinay, G., H. Decamps, C. Arles, and M. Lacassinseres. 1989. Topographic Influence on Carbon and Nitrogen Dynamics in Riverine Woods. Archiv Fur Hydrobiologie 114:401414.

Pinay, G., and R. J. Naiman. 1991. Short term hydrologic variations and nitrogen dynamics in beaver created meadows. Archiv für Hydrobiologie 123:187-205.

Pinay, G., T. O'Keefe, R. Edwards, and R. J. Naiman. 2003. Potential denitrification activity in the landscape of a western Alaska drainage basin. Ecosystems 6:336-343.

Pinay, G., L. Roques, and A. Fabre. 1993. Spatial and Temporal Patterns of Denitrification in a Riparian Forest. Journal of Applied Ecology 30:581-591.

Pinay, G., C. Ruffinoni, and A. Fabre. 1995. Nitrogen cycling in two riparian forest soils under different geomorphic conditions. Biogeochemistry 4:1-21.

Poff, N. L. 2002. Ecological response to and management of increased flooding caused by climate change. Phil. Trans. R. Soc. Lond. A. 360:1497-1510.

Ponnamperuma, F. N. 1972. The chemistry of submerged soils. Advances in Agronomy 24:29-96.

Reddy, K. R., and W. H. J. Patrick. 1975. Effect of alternate aerobic and anaerobic conditions on redox potential, organic matter decomposition and nitrogen loss in a flooded soil. Soil Biology and Biochemistry 7:87-94.

Reynard, N. S., C. Prudhomme, and S. M. Crooks. 2001. The flood characteristics of large U.K. rivers: potential effects of changing climate and land use. Climatic Change 48:343359.

Richards, G. R. 1993. Change in global temperature: a statistical analysis. Journal of Climate 6:546-559.

Robson, A. J. 2002. Evidence for trends in UK flooding. Phil. Trans. R. Soc. Lond. A. 360:1327-1343.

Rolston, D. E., P. S. C. Rao, and J. M. Davidson. 1984. Simulation of denitrification losses of nitrate fertilizer applied to uncropped, cropped and manure-amended field plots. Soil Science 137:270-279

Roy, L., R. Leconte, F. P. Brissette, and C. Marche. 2001. The impact of climate change on seasonal floods of a southern Quebec River basin. Hydrological Processes 15:31673179.

Sabater, S., A. Butturini, J. C. Clement, T. Burt, D. Dowrick, M. Hefting, V. Maitre, G. Pinay, C. Postolache, M. Rzepecki, and F. Sabater. 2003. Nitrogen removal by riparian buffers along a European climatic gradient: Patterns and factors of variation. Ecosystems 6:2030 . 
Salo, J., R. Kalliola, J. Häkkinen, Y. Mäkinen, P. Niemelä, M. Puhakka, and P. B. Coley. 1986. River dynamics and the diversity of Amazon lowland forest. Nature 332:254-258.

Schimel, D. S., M. R. Stillwell, and R. G. Woodmansee. 1985. Biochemistry of C, N and P in a soil catena of the shortgrass steppe. Ecology 66:276-282.

Schlesinger, W. H., J. A. Raikes, A. E. Hartley, and A. F. Cross. 1996. On the spatial pattern of soil nutrients in desert ecosystems. Ecology 77:364-374.

Schlosser, I. J., and J. R. Karr. 1981. Riparian vegetation and channel morphology impact on spatial patterns of water quality in agricultural watersheds. Environmental Management 5:233-243.

Seely, B., K. Lajtha, and G. D. Salvucci. 1998. Transformation and retention of nitrogen in a coastal forest ecosystem. Biogeochemistry 42:325-343.

Shaver, G. R., J. Canadell, F. S. I. Chapin, J. Gurevitch, J. Harte, H. Greg, P. Ineson, S. Jonasson, J. Melillo, L. Pitelka, and L. Rustad. 2000. Global warming and terrestrial ecosystems: a conceptual framework for analysis. Bioscience 50:871-882.

Stone, M. C., R. H. Hotchkiss, C. M. Hubbard, T. A. Fontaine, L. O. Mearns, and J. G. Arnold. 2001. Impacts of climate change on Missouri River Basin water yield. Journal of the American Water Resources Association 37:1119-1129.

Technicon, (1976) Technicon instrument system. Technicon method guide. Technicon, Tarrytown, New York.

Veldkamp, A., and L. A. Tebbens. 2001. Registration of abrupt climate changes within fluvial systems: insights from numerical modelling experiments. Global and Planetary Change 28:129-144.

Vitousek, P. M. 1994. Beyond global warming: ecology and global change. Ecology 75:1861-1876.

Vörösmarty, C. J., and D. Sahagian. 2000. Anthropogenic disturbance of the terrestrial water cycle. Bioscience 50:753-765.

Yoshinari, T., and R. Knowles. 1976. Acetylene inhibition of nitrous oxide reduction by denitrifying bacteria. Biochemical and Biophysical Research Communications 69:705710 . 
Table 1: Main characteristics of the rivers under study

\begin{tabular}{|c|c|c|c|c|c|c|c|}
\hline & & & & & & & \\
\hline & Aar & Danube & Garonne & Helge & Po & Trent & Vindel \\
\hline Latitude N & 47 & 42 & 44 & 56 & 44 & 52 & 64 \\
\hline Mean annual $\mathrm{T}^{\circ} \mathrm{C}$ & 8.1 & 10.6 & 13.1 & 6.7 & 14.5 & 10.0 & 1.3 \\
\hline Mean January $\mathrm{T}^{\circ} \mathrm{C}$ & 1.0 & -1.3 & 5.5 & -0.6 & 4 & 3.9 & -12.8 \\
\hline Mean July $\mathrm{T}^{\circ} \mathrm{C}$ & 17.6 & 22.0 & 21.5 & 16.7 & 26 & 16.5 & 14.4 \\
\hline $\begin{array}{l}\text { Mean annual } \\
\text { Precipitation }(\mathrm{mm})\end{array}$ & 1169 & 408 & 671 & 698 & 664 & 766 & 585 \\
\hline $\begin{array}{l}\text { Month of max } \\
\text { Precipitation }\end{array}$ & Nov & June & May & July & Oct. & Dec. & \\
\hline Mean (mm) & 80 & 65 & 80 & 77 & 71 & 80 & 88 \\
\hline $\begin{array}{l}\text { Month of min } \\
\text { Precipitation }\end{array}$ & \multicolumn{2}{|c|}{ March Jan. } & July & May & Feb. & July & April \\
\hline Mean (mm) & 72 & 16 & 46 & 33 & 38 & 48 & 25 \\
\hline $\begin{array}{l}\text { Mean daily } \\
\text { Discharge }\left(\mathrm{m}^{3} \mathrm{~s}^{-1}\right)\end{array}$ & 247 & 6032 & 202 & 22 & 1500 & 81 & 180 \\
\hline $\begin{array}{l}\text { Month of max } \\
\text { Discharge }\end{array}$ & June & April & May & April & May & Feb. & June \\
\hline Mean & 686 & 8473 & 378 & 34 & 1960 & 153 & 562 \\
\hline $\begin{array}{l}\text { Month of min } \\
\text { Discharge }\end{array}$ & Dec. & Sept. & Sept. & Aug & Aug & Sept & March \\
\hline Mean & 62 & 4231 & 86 & 10 & 971 & 40 & 34 \\
\hline
\end{tabular}


Table 2: Ranking of predictors for denitrification by order of importance. The predictors are soil moisture (SM), temperature (TEMP), nitrate (N), herbaceous plant biomass (HPB), and soil texture (SSC). - GCV is the loss in Generalized Cross-Validation when all basis functions involving the corresponding predictor are removed from the final model. Importance (\%) is the relative importance of predictors as compared to the best one (soil moisture here).

\begin{tabular}{lll}
\hline Predictor & Importance & $-\mathrm{GCV}$ \\
\hline Soil Moisture (SM) & 100 & 719.980 \\
Temperature (TEMP) & 78.349 & 632.551 \\
Nitrate (N) & 68.036 & 598.368 \\
Herbaceous Plant Biomass (HPB) & 13.708 & 497.817 \\
Soil texture (SSC) & 0 & 493.562
\end{tabular}




\section{Figure captions}

Figure 1: Map of the rivers under study in Europe. The dots refer to the study areas along the different rivers.

Figure 2: Relationship between denitrification activity and alluvial soil variables. All the data from the different study sites were combined. A: Denitrification rates and soil moisture. B: Denitrification rates and soil texture expressed as percentage of silt plus clay. C: Denitrification rates and riparian soil nitrate content. D: Denitrification rates and herbaceous plant biomass in the riparian sites. E: Denitrification rates and soil temperature.

Figure 3: Relationship between riparian soil temperature and denitrification activity in the different rivers under study.

Figure 4: A: Monthly denitrification activity in the soils of the Garonne riparian zones - B: Monthly variations of the Garonne River discharge $-\mathrm{C}$ : Monthly variations of the riparian soil temperature - D: Monthly variations of rainfall in the study sites along the Garonne River. Box 1 underlines a period with moderate rainfall and high soil temperature. Box 2 underlines a high water period with low soil temperature.

Figure 5: A: Monthly denitrification activity in the soils of the Po riparian zones - B: Monthly variations of the Po River discharge $-\mathrm{C}$ : Monthly variations of the riparian soil temperature - D: Monthly variations of rainfall in the study sites along the Po River. Box 1 underlines a period with rainfall and floods. Box 2 underlines summer rainfall event. 


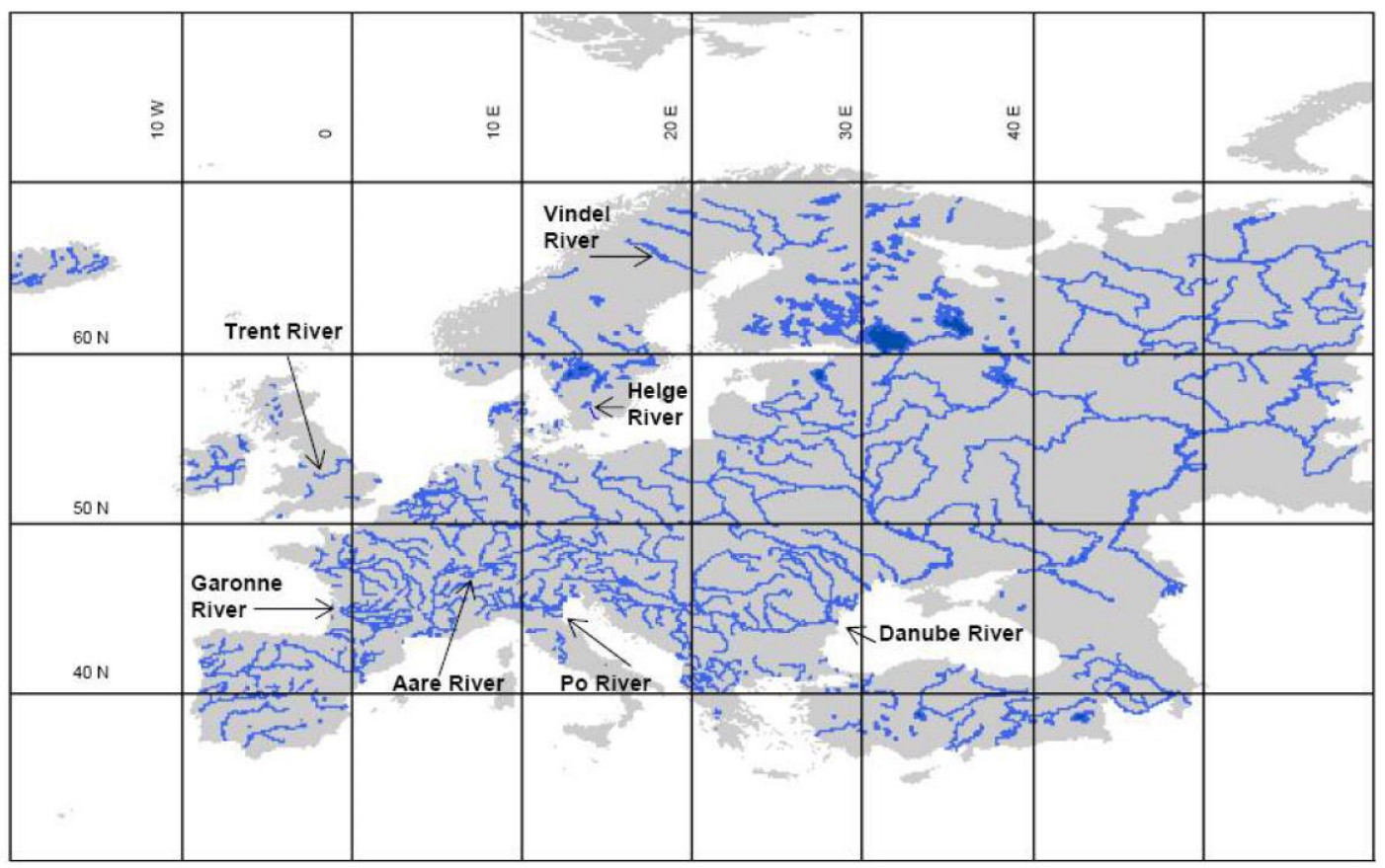

Pinay et al. Figure 1 

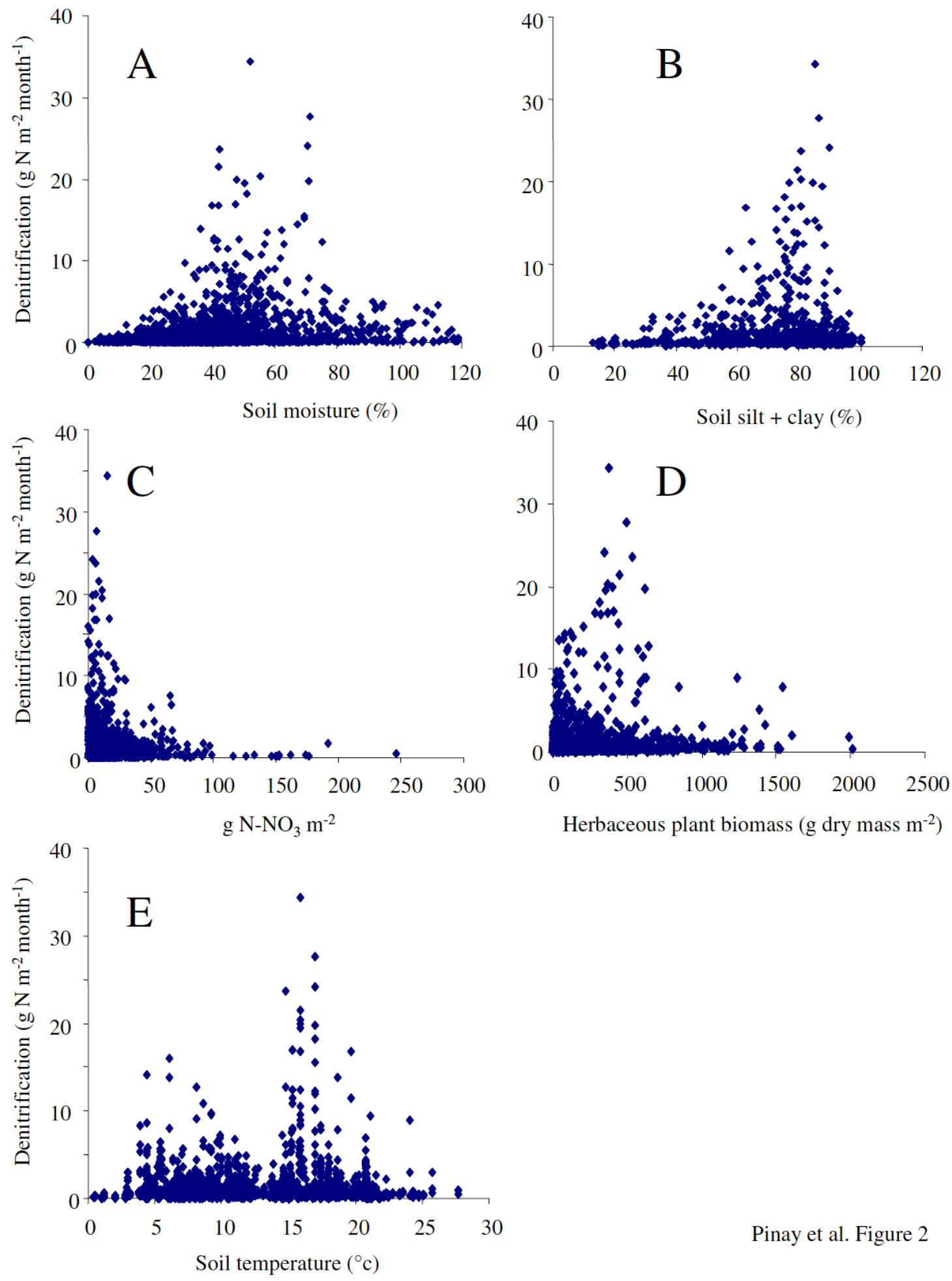

Pinay et al. Figure 2 

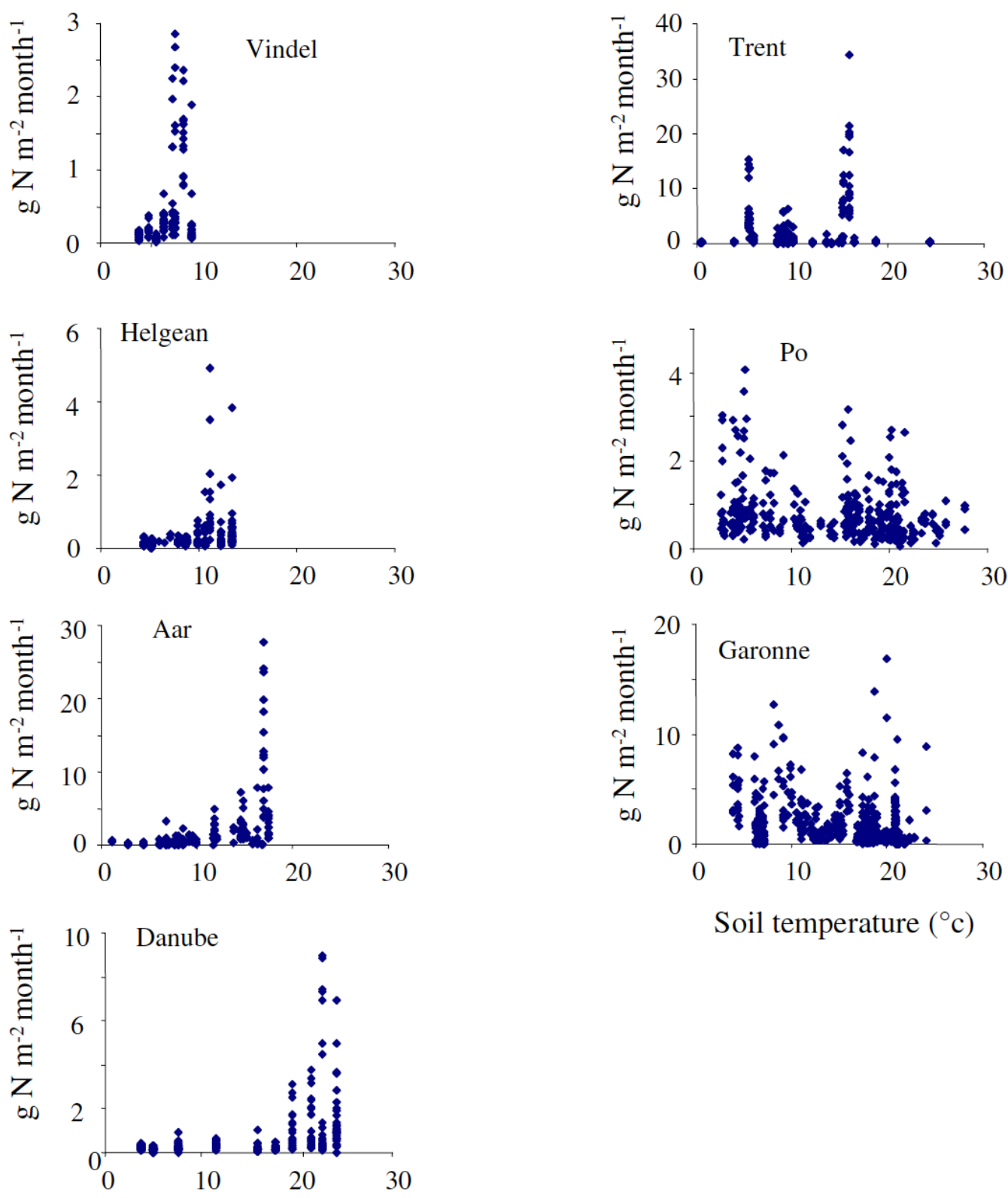

Soil temperature $\left({ }^{\circ} \mathrm{c}\right)$

Soil temperature $\left({ }^{\circ} \mathrm{c}\right)$

Pinay et al. Figure 3 


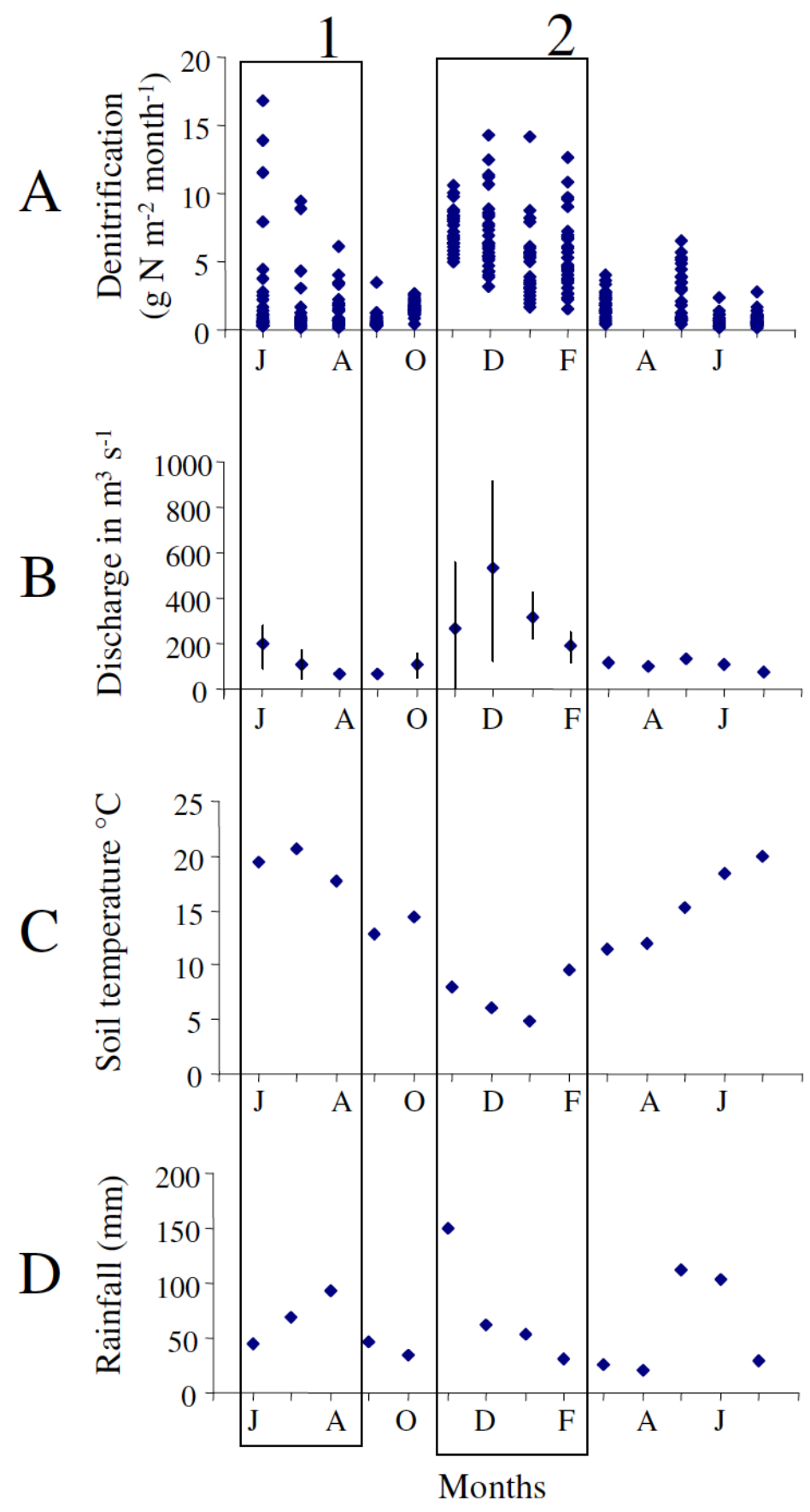

Pinay et al. Figure 4 


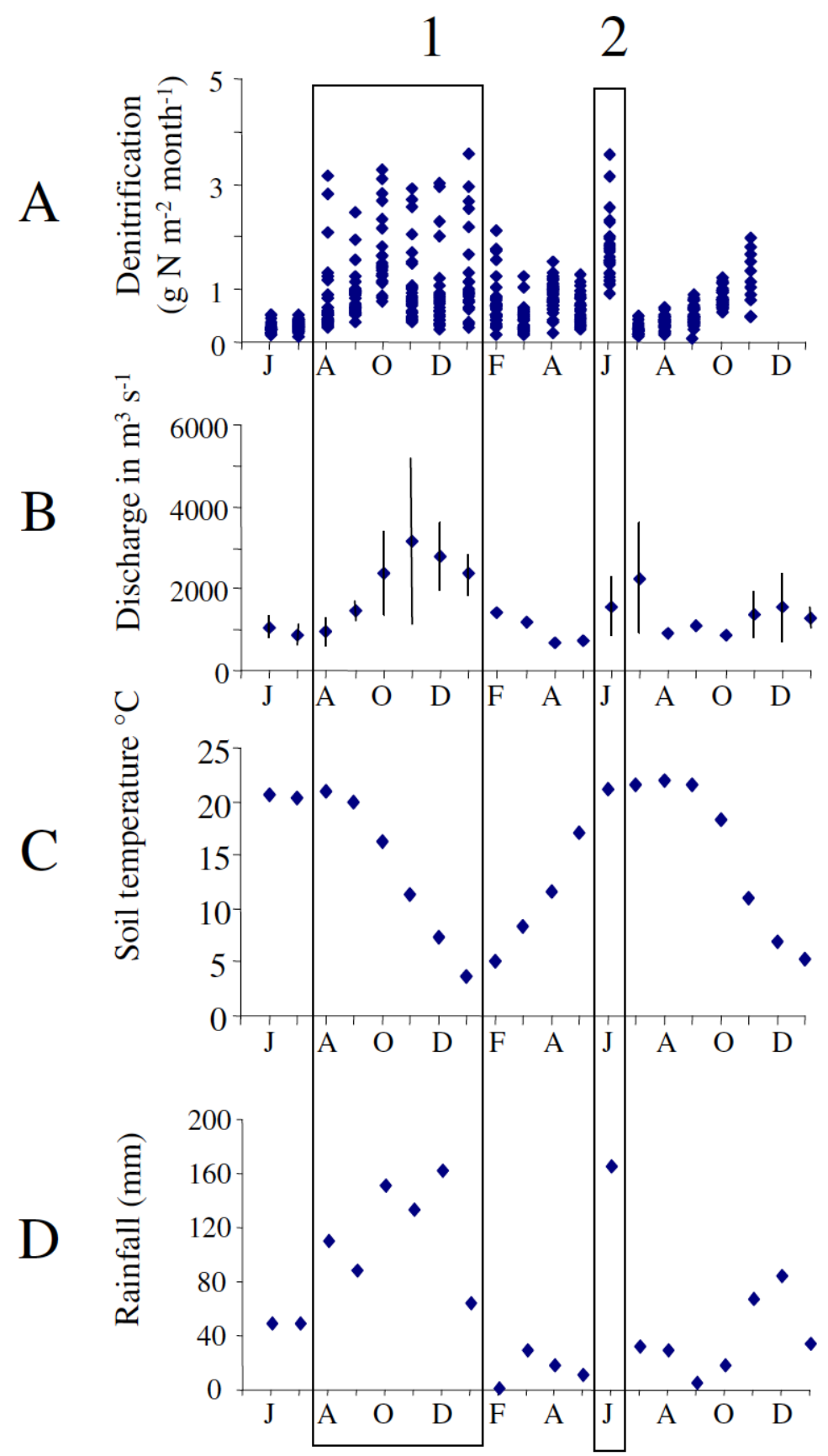

Months

Pinay et al. Figure 5 